\title{
Three Shades of Red: Power of Symbols or Soviet Legacy in Contemporary Inner Asian Capitals
}

\begin{abstract}
The paper focuses on Soviet symbols in Inner Asian capitals and the conflicts around socialist legacy. We analyze Ulaanbaatar, Kyzyl, and Ulan-Ude as three different models of transformation of political symbols in urban space. All three capitals in their names contain the word "red" semiotically associated with communist ideology. Correspondingly, we see three different models of symbolic struggle for urban space. Theoretically, the paper is based upon the model of symbolic politics. Empirically, the research is based on materials of our own observations, discourse analysis of media, and official municipal documents. In general, the research is an analysis of symbolic practices of power in the conditions of a number of complex changes in Inner Asia.
\end{abstract}

Keywords: capital, power, genealogy, Inner Asia, Socialistic brotherhood, symbol, memorials

This research is an attempt to answer questions about how stable Soviet political symbols are in Inner Asian capitals and the reasons for this. This article considers the capitals of Buryatia (Ulan-Ude), Mongolia (Ulaanbaatar), and Tuva (Kyzyl), which are united by Soviet heritage (Hatherley 2016). These culturally and ethnically close regions have gone through a difficult phase of development since the collapse of the USSR and the "Eastern Bloc". Each of these capitals overcame the unifying principles of Soviet nationality policy and acquired their own unique political symbols, marking a new stage in nation-building. However, the Soviet legacy remains a burning issue, in official Russian political rhetoric.

Given these conditions, it is important to focus on the capital status of the cities under study. All of them were once the capitals of independent states or are the ones to this day, like Ulaanbaatar. In 1920, Verkhneudinsk (Ulan-Ude) 
was the capital of the Far Eastern Republic for a short time, while Kyzyl was the capital of the Tuvan independent state until 1944. Today, they are the capitals of the national subjects of the Russian Federation. The status of the capital implies an important function of representing the national culture of the people, which is a constitutionally enshrined source of power (Therborn 2017). At the same time, Soviet symbols appeal to a kind of imaginary civilizational unity that unites the vast geopolitical space from the Baltic to the Pacific Ocean.

The end of the Soviet metanarrative also substantially changed the face of Inner Asia, despite the relatively non-conflict process of de-Sovietization. The political space of regional capitals was nationalized. In most cases, Soviet symbols were harmoniously integrated into the new design. However, the actualization of the Soviet design in the 2010s led to the emergence of a number of symbolic conflicts. From a hypothetical perspective, it can be assumed that twenty years after the collapse of the USSR, the meanings associated with the Soviet era have transformed, and the new frames have come into conflict with the sign-symbolic system that developed during the reforms of the 1990s.

The structure of this article assumes three research plots in three capitals; de facto these are three models of the integration of the Soviet political heritage in the symbolic space of national capitals. Despite the significant differences between the three selected capitals, the reference point for the study is the generality of post-socialist features in the conditions of the Buddhist core of nomadic Asia.

This work continues the academic tradition of studying Inner Asian cities. The researchers who had an intellectual influence on the development of urban studies in Inner Asia are as follows: A. Breslavsky, C. Humphrey, N. Karbainov, I. Peshkov, T. Skrynnnikova, Z. Szmyt, V. Terentev, and B. Zhimbiev. Over the past thirty years, a clear idea has been formed about how the processes of urbanization and ruralisation have developed in the post-communist and post-nomadic societies of Inner Asia. The identified patterns allow consideration of the problem of the power of symbols in the capitals of the region from comparative perspective.

This article is based on the author's personal observations. However, the power of symbols is not only about material symbols of hegemony (monuments, street names, political symbols in architecture) but also about texts. They form and reproduce the meanings associated with the continuity and kinship of power legitimizing regimes. The key concept in this situation was "kinship" borrowed from the Soviet ideological heritage of the "fraternal international community of peoples"; therefore, the empirical base of the study included regional texts of the Soviet period, materials of the modern press, and publicly-funded statistics.

Theoretically, the work of Forest and Johnson was the most important for the preparation of this study. Their thesis is fundamental to the author's fieldwork:

During change and crisis, political actors employ monuments and memorials as vehicles to legitimate their claims on power and their visions of society. These symbols, in turn, declare publicly which groups and histories the official sphere recognizes as central to the state's identity. 
They reveal and reify the state's level of inclusiveness - not simply designating who belongs to and in the state, but who may legitimately aspire to political power. They also make material claims about a state's identity in relation to other states, suggesting everything from shared values and past cooperation to ideological conflict and historical enmities (Forest, Johnson 2011: 270).

During the study, an attempt will be made to find the interrelation between political changes and the preservation of the Soviet symbolic heritage in the urban spaces of Ulaanbaatar, Kyzyl, and Ulan-Ude. It is important to understand what has changed after the collapse of the USSR: the meanings attributed to socialist symbols, the composition of the political elite, or the power legitimizing regimes. The structure of this article is subordinated to this logic, where the symbols of power in the three Asian capitals will be studied using a comparative analysis.

\section{Case 1. Ulaanbaatar}

Ulaanbaatar or "Red Hero" got its name in 1924 against the background of revolutionary transformations in the country. The uniqueness of Ulaanbaatar lies in the fact that it is the second capital of a socialist state in the world. Also, according to the duration of the Soviet ideological influence on the urban architecture, Ulaanbaatar ranks second after Moscow. This fact is often ignored by researchers of landscapes of the socialist period. Symbols, facades, space organization - all this testifies to a long-term orientation towards the Soviet Union. The three communist marshals (Stalin, Choibalsan and Zhukov) are iconic figures for this region. Back in 2004, the author of this article detected the Stalinist design of the central square and the administrative buildings located on it. However, the city has changed a lot since then. The process of overcoming the communist legacy went unevenly for a long time, but without any particular shocks.

Today, the case of the Mongolian capital is the most striking example of conflict-free decommunization of symbolic space. This is largely due to the political elite transformation that took place in the 1990s. The orientation towards liberal values and the role of nationalism in this process are described in sufficient detail in the scientific literature. According to a number of researchers, the "anti-colonial nationalism" of the 1990s provided a change in the sign-symbolic codification of the public space of power in the Mongolian capital. Farewell to the Soviet legacy on a rhetorical level was associated primarily with the ineffectiveness of the economic model of development. One of the ideologues of Mongolian democracy noted philosophically: "For 70 years they have been carrying cereals along the wrong road" (Lishtovanny 2007: 78). Illustrating the current situation, Kaplonski wrote: "During the democratic revolution, the 'democratic forces' were quick to capitalize on the potential of historical symbolism. They drew upon Genghis Khan, Buddhism and the classical Mongolian script (mongol bichig) to position 
themselves as the true inheritors of tradition and custom. Even when the point was not made explicitly, the use of historical imagery was meant as an anti-colonial statement" (Kaplonski 2004: 71).

The first decade after the winter revolution of 1989-1990 was devoted to the formation of a new national idea. The search for this idea in the past led to the choice of plots from the times of Genghis Khan's empire as the starting points for the emergence of statehood. As a result, a new genealogy of political institutions emerged, based on medieval symbolism, with a great influence of Buddhism. These symbols subsequently replaced the codes of Soviet political hegemony, although they did not completely displace them.

The transformation of the urban space of Ulaanbaatar lasted for several years. First of all, the principle of space organization changed: the mausoleum of Sükhbaatar and Choibalsan in the central square of the country was liquidated in 2005. The bodies of the revolutionary leaders were cremated and reburied according to the Buddhist rite. At the same time, the redevelopment of the building of the Government Palace, located next to the mausoleum, began. The Government Palace was an example of a monumental building of the early 1950s and an architectural symbol of the socialist era. In 2005, this nationalization of the design of the country's main administrative building began. Today, it is decorated with a statue of Genghis Khan and his descendants: Ögedei and Khubilai khans, as well as his bodyguards: Mukhali and Boorchu. The architectural reform of the central square at the symbolic level consolidated the new ideological attitudes and principles of the state structure of modern Mongolia. The name of Sükhbaatar Square also changed twice. In 2010, it was renamed Genghis Khan Square, and in 2016, its former name was taken back by the decision of the Supreme Court.

The uniqueness of the Mongolian version of de-Sovietization is manifested in the war against monuments. In the wake of de-Sovietization, one of the first dismantled monuments in the Mongolian capital was the memorial of Stalin at the National Library in Ulaanbaatar. Erected in 1949, this monument has successfully "survived" all the vicissitudes of the $20^{\text {th }}$ Communist Party Congress due to the personal political will of Tsedenbal. The four-meter sculpture of Stalin was dismantled on December 22, 1990, accompanied by a shamanic ritual for the repose of the spirit of the deceased. This late parting with the symbol of Stalinism also meant a change in the political elite. The new leaders represented a completely different generation of politicians that emerged under the conditions of late socialism.

As for the monuments to Lenin, the most famous of them, which stood in the city centre opposite the Ulaanbaatar hotel, was removed only in 2012. The idea to liquidate the monument belonged to the mayor of the capital, the leader of the Democratic Party Bat-Uulu. The politician said:

Communists are criminals not only towards those countries to which they imposed their ideology, but also towards their own people. The monument to Lenin had to be taken away because 
it is a reminder of the massive repression in Mongolia. During the reign of Lenin and Stalin, thousands of Mongols became victims of political repression (Yan 2012: 6).

Despite this, the author of this article explored the city centre and managed to find a surviving monument. Located near the former House of Pioneers is a memorial to the schoolboy Lenin. In contrast to the demolished monument, the inscription on the curbstone is made in old Mongolian hieroglyphics. According to local residents, the gymnasium format and the inscription in Old Mongolian saved the monument from liquidation.

As for other surviving memorials, mention should be made of the bust of Shchetinkin, who worked as an instructor for the Mongolian special services and died in Ulaanbaatar in 1927. Like the monument to the schoolboy Ulyanov, this memorial is an abandoned sculpture on Peace Avenue - the central street of the Mongolian capital. Shchetinkin was not only a Red Army partisan and a hero of the war against Ungern but also one of the founders of the State Internal Guard of Mongolia, which was responsible for political repression in the country.

Overcoming Soviet symbolism in the urban space of Ulaanbaatar is a process that went one for almost 25 years (Plueckhahn 2020). During this time, a new sign-symbolic system was formed, constructing a genealogy from Genghis Khan's empire. However, it also acquired a hybrid form. Many Soviet political symbols dissolved in the new space, contributed to the next stage of nation-building. For example, the Zaisan Memorial is more a monument of military glory than a symbol of ideological domination. Once on the periphery, Soviet symbols continue to exist in oblivion, excluded from commemorative projects. Besides, all the war memorials created by the Soviet army in Mongolia are now included in the system of memorials of military glory under the protectorate of Russia and have significantly transformed under the influence of the Orthodox Church.

\section{Case 2. Kyzyl}

Kyzyl, translated from Tuvan as "Red", called Belotsarsk until 1926, did not undergo such a complex transformation after the collapse of the USSR as Ulaanbaatar. Nowadays Kyzyl, which received the status of a national capital thanks to the revolution in Russia and the national policy of the Bolsheviks, still remains one of the cities with a special temporality. Despite the complex socio-economic transformations during the Putin era, this city froze at the turn of the eras. Attempts to overcome the Soviet and comprehend the past stand side by side with the Lenin Monument, which has become part of the Tuvan national landscape. The national is considered as timeless, as opposed to the global trend towards modernization. Stalinist Empire style architecture appears in contrast, adjacent to modern buildings. A visual example is on Red Partisans Street with its "Noble Nest" (a house built exclusively for the Soviet political elite of Tuva), which once 
symbolized the domination of the Soviet party nomenclature. In this case, there is a direct analogy with The House of Government by Yuri Slezkine (2017) but the situation in Kyzyl is distinguished by a rich Asian flavour and a different attitude to the authorities. This is connected to the legacy of the Tuvan People's Republic, which was a sovereign state until it joined the RSFSR (Russian SFSR) in 1944. The period of the People's Republic in Soviet ideology was characterized by a non-capitalist path of development, that is to say, the preparation time for the transition to socialism. This made it possible to partially preserve elements of traditional culture and nomadic cattle breeding. The final transition to sedentarization in Tuva would begin only after 1944 . This political context had a tremendous impact on the character and composition of the party and administrative elite in the region, which retained its ethnocultural identity even under the conditions of the Great Purge.

The genealogy of the local political elite is directly rooted in the Soviet period between 1944-1990. However, Yeltsin's thesis ("Take as much sovereignty as you want") influenced the transformation of the symbolic space of power. The Tuvan capital, without eliminating Soviet symbols, began to nationalize its urban space. One of the first symbols of modern times was the Museum of the History of Political Repression, founded in 1994. In 1996, during the wave of de-Sovietization, a monument to the victims of political repression "Invincible Arat (Invincible Tuvan herder)" was erected. The victims of repression were representatives of the political and cultural elite of the Tuvan People's Republic, which was an independent state until 1944 (Mongush 2006).

The war with monuments in Tuva had a pronounced regional specificity. In the early 1990s, a bust of Salchak Toka was almost desecrated by those who blamed the statesman for political repression in Tuva. As a result, in 1992, the monument was enclosed in a wooden box indefinitely. Such a precedent is unique in Inner Asia since it was an example of punishment through oblivion.

However, the deprived rural area of Tuva in the post-Soviet period had the most difficult economic situation of all three territories under study. The implementation of regional image projects, such as the obelisk symbolizing the Center of Asia, required significant financial investments. The renovation of memorials became possible due to the centenary of the unification of Tuva and Russia, which was celebrated in 2014. Funds for this project were allocated from the republican and federal budgets to update the external appearance of Kyzyl. As a result, the third composition "The Center of Asia" (the first being pre-revolutionary, and the second during Soviet times) was installed only in 2014 according to the project of Dashi Namdakov. Besides, a monument to gun-noion Buyan-Badyrgy, the founder of Tuvan statehood, was erected as part of the anniversary events. At the same time, there are references to the history of Genghis Khan's empire, in particular, in the name of the sports complex "Subedei" in honour of one of the cohorts of the empire founder. 
Today the monument to Lenin in Kyzyl is balanced by a large-scale inscription of a Buddhist mantra in Tibetan on a nearby hill. The inscription on the monument says: "To V.I. Lenin from the Tuvan people". Also, the monument stands with its back to the mantra, pointing in the direction of Mongolia with its hand. The symbolism of this gesture is of no small importance to the level of public understanding of Soviet political symbols. The monument is located near the building of the Great Khural of Tuva and Arat Square. Thus, the city's layout meets the standards set in the USSR - the central square, central Lenin Street, a monument to Lenin, administrative buildings. As a result, a hybrid model of symbolic space, combining symbols of two eras, was formed in Kyzyl.

An important place among Soviet symbols is occupied by the monument to the Red Army Partisans of 1954. It is a four-sided stele with a bas-relief on one side, crowned with a red star. The memorial was erected at the place of the common grave of 47 partisans who died in battles with the Cossacks of Esaul Bogolov in 1918. The names of the killed partisans were inscribed on the pediment only in 1984 . This monument directly echoes the bust of Shchetinkin in Ulaanbaatar, since he also commanded Tuvan partisans. It should be noted that all the memorial works were closely related to the anniversary of the entry of the Tuvan People's Republic into the USSR: in 1954 - with 1984 marking the $40^{\text {th }}$ anniversary.

Another important political symbol of the socialist era is the building of the Great Khural of Tuva. This architectural monument of the Stalinist era was built in 1942 as the Government House: it is a three-storey building in the classical style with national elements. These elements are clearly manifested in the golden dome, which is more characteristic of Buddhist temples. Unlike Ulaanbaatar, this building was not rebuilt in accordance with new political trends. On the contrary, it has been conserved as an architectural monument.

The complex system of relationships within the political elite of the Republic of Tuva led to the eclecticism of political symbols in the streets of Kyzyl. Representatives of various political clans in the region define their own legitimacy in different ways (Lamajaa 2010). Besides, references to the Soviet period do not depreciate the symbolic capital of a particular group. The very genealogy of modern political institutions in Tuva refers to the $20^{\text {th }}$ century. The existing hybrid form of political symbols in the capital of Tuva simultaneously appeals to both the period of the independent Tuvan People's Republic and the Soviet period. As a result, in this region, in contrast to neighbouring Mongolia, the rethinking of the Soviet does not lead to a large-scale change of political symbols.

\section{Case 3. Ulan-Ude}

The former capital of the Far Eastern Republic and the capital of Buryatia nowadays is located in the valley of the Selenga and Uda rivers, one of which gave its 
name to the city in 1934 (Ulan-Ude is translated as "Red Uda") (Zhimbiev 2000). Today Ulan-Ude is an example of the sustainable naturalization of Soviet symbols in the urban space. This is largely due to the fact that the modern political elite of Buryatia has inherited Soviet party nomenclature. According to various estimates, up to $60 \%$ of its representatives are family members of Soviet party and state leaders. The influence of de-Sovietization in this city is almost untraceable due to the fact that the President of Buryatia was a communist from the period of the collapse of the USSR until 2006. The region entered the $21^{\text {st }}$ century with the burden of linguistic, national, and social contradictions. Political clans representing the modern Buryat establishment are genealogically linked to the Soviet period. The very emergence of statehood in this region is the result of Lenin's decree On the Right of Nations to Self-Determination. V.I. Lenin's ideas served as the basis for the formation of the autonomous republics of the RSFSR (Russian SFSR) and subsequently became the foundation for the entire Soviet nationality policy. The political self-determination of the peoples of Siberia and the Far East began with the creation of the Yakut (Yakut Autonomous Soviet Socialist Republic) and Buryat (Buryat Autonomous Soviet Socialist Republic) republics in 1922 and 1923.

The city centre is planned according to the Soviet template: the main square is Soviets Square with adjoining administrative buildings and Lenin Street. Soviets Square is famous for the monument located here - the world's largest head of Lenin. It was conceived for the centenary of the revolution leader in 1970 and installed a year later in 1971 . This memorial entered the $21^{\text {st }}$ century without visible changes, as well as without serious attempts to eliminate this symbol legitimizing the right to statehood in Buryatia. The building of the People's Khural (House of Parliament) located nearby is decorated with the emblem of the USSR, and the building of the government and city hall - with the symbols of the Russian Soviet Federative Socialist Republic. The entire composition of Soviets Square and the adjacent buildings is a monument of Soviet architecture. Touching upon the theme of the house of power, one should also note the presence of the "Noble Nest" in Ulan-Ude and Kyzyl, which was the home of party nomenclature at first and subsequently - the regional elite. Located in the city centre on Profsoyuznaya Street, this building contrasts with the modern concept of the suburban location of elite housing. Today, it is more a political symbol of a bygone era than an actual seat of power.

However, Ulan-Ude also survived the influence of nationalism, which was reflected in city symbols. National symbols, referring to the medieval archaism, can be traced in the whole complex of symbols that mark the urban space as the capital of the national republic. Monuments to the Bogatyrs (epic heroes), King Gesar (epic king, the fearless lord of the legendary kingdom of Ling), and a number of other mythical characters, erected in the post-Soviet period, are closely intertwined with socialist symbols. "National in form, socialist in content" is a formula of the Soviet period, in which meanings have changed places at the present stage 
(Breslavsky 2012). The socialist form became the basis for the national project, which was developed in political settings in the $21^{\text {st }}$ century: as in Tuva's case, the design of political institutions was largely copied from the Soviet standard.

The manifestation of power in relation to urban space is associated with the traditions of the Soviet period. It manifests itself in the memorials dedicated to the Second World War, erected in 2000-2010. At the present stage, most of these memorials have a certain connection with the history of the war in the context of national memory in the Republic of Buryatia. Soviet history, associated with the formation of statehood, is becoming increasingly sacred, since it consolidates the right to the hegemony of certain political interest groups. A feature of Buryatia was the uncritical perception of the Soviet sign-symbolic system in the urban space, which made it possible to transform imperial Verkhneudinsk into the capital of the national republic - Ulan-Ude.

In this situation, Soviet symbols become an important part of usable past and therefore are constantly updated and repaired. These symbols have largely acquired new political meanings, which were created in the process of post-Soviet nation-building. Forgotten meanings are no less important. First, the ideology of Marxism was forgotten; it was replaced by nationalism. The issues of industrialization and political repression also remained in the periphery of the city's symbolic space. This is largely due to partial demodernisation and a different understanding of the genealogy of the state.

In this regard, it is important to trace the differences between Soviet Ulan-Ude as an industrial city and post-Soviet Ulan-Ude as the national capital. In the latter, monuments to workers and industrial memorials became completely unnecessary and were pushed into oblivion. Although, along with the monuments to Lenin, they formed the basis of Soviet symbols. The modern city began to combine Soviet leaders, the theme of victory in the war, with impersonal memorials to medieval mythological heroes who replaced the objects of industrial memory.

The end of the period of Soviet power in Buryatia did not lead to the devaluation of its political symbols. Their reframing in parallel with nomenclature restoration created an entirely new space of hegemony. Monumental Lenin in the main square of the city consolidates the nation's right to the state and, as a consequence, to the redistribution of political and economic resources. In this context, ethnic and Buddhist symbols only complement the city landscape, emphasizing the right to one's own interpretation of the heritage of a recent era. It is obvious that the current system consolidates the balance of power in the region. That is why attempts to introduce elements of the heritage of the Russian Empire into the city's space are unsuccessful and assessed as alien and colonial. 


\section{Conclusion}

The three red Inner Asian capitals, with a common resemblance and cultural affinity, represent three models of using Soviet symbols in a public urban space. These symbols are closely related to the anti-imperialist nationalism of the first half of the $20^{\text {th }}$ century and, in some cases, retain this political meaning. Following the post-Marxist tradition (Therborn 2017), the authors rely on the thesis that urban symbolism is one of the ways for the authorities to communicate with the population. In this context, Ulaanbaatar manifests the dynamic of post-Soviet nationalism. This can be clearly seen through the example of the dismantling of the main objects of Sükhbaatar Square and the spread of new architectural and memorial forms. An example is a monument to the leader of Mongolian democracy Zorig.

For the Inner Asian nomads, socialism was a period of not only accelerated modernization and nation-building, but also cultural trauma. Socialist culture, with its trend towards Westernization, destroyed the entire nomadic way of life, but created the basis for a modern state. The use of medieval symbols in the urban landscape compensated for cultural trauma. It makes up for the ignorance in the Soviet period of Genghis Khan, Gesar and other images of khan-feudal culture. As a result, the updated version of this culture is closely intertwined in the urban landscape with the industrial symbols of socialism.

In the case of Ulan-Ude and Kyzyl, the manifestation of Soviet symbols became an act of consolidating the legitimacy of national state institutions. In contrast to Mongolia, national statehood in Buryatia and Tuva has been preserved in a more conservative version. The organization of the space of the capitals with their streets named after Lenin and the external attributes of Soviet power testifies to the crucial difference between the political challenges faced by the local elite. The system of relations "centre-national outskirts" that has developed in the USSR is reproduced by the Russian Federation with significant changes. Hence, there is a tendency to preserve continuity and the status quo at least at the level of state symbols.

All three studied examples are united by the fact that in relation to names, the three Inner Asian capitals are still revolutionary red. Similarities remain in the spatial organization of power: the central square and the Government Palace were created according to Soviet templates. In addition, the set of political names for streets and memorials also remains the same: Sükhbaatar, Shchetinkin, partisans. However, despite numerous discussions, the opponents of revolutionaries have never been enshrined in the symbolic space of these cities. 


\section{Bibliography}

Breslavsky A.S.

2012 Post-Soviet Ulan-Ude: Content and Meaning of a New Urban Idea, "Inner Asia", vol. 14 (2), pp. 299-317.

Forest B., Johnson J.

2011 Monumental Politics: Regime type and Public Memory in Post-communist States, "Post-Soviet Affairs", vol. 3 (27), pp. 269-288.

Hatherley $\mathrm{O}$.

2016 Landscapes of Communism: A History Through Buildings, New York.

Humphrey C.

1991 'Icebergs', Barter, and the Mafia in Provincial Russia, "Anthropology Today", vol. 2 (7), pp. 8-13.

Humphrey C. (ed.)

2007 Urban Life in Post-Soviet Asia, London.

Kaplonski C.

2004 Truth, History and Politics in Mongolia. Memory of Heroes, London.

Lamajaa Ch.

2010 Clannishness in the Politics of the Regions of Russia. Tuvan Rulers, Moscow.

Lishtovanny E.

2007 From Great Imperia to Democracy: Essays on the Political History of Mongolia, Irkutsk.

Mongush M.

2006 Modern Tuvan Identity, "Inner Asia”, vol. 2, pp. 275-296.

Peshkov I.

2014 Usable Past for a Transbaikalian Borderline Town. 'Disarmament' of Memory and Geographical Imagination in Priargunsk, "Inner Asia”, vol. 1 (16), pp. 95-115.

Plueckhahn R.

2020 Shaping Urban Futures in Mongolia. Ulaanbaatar, Dynamic, Ownership and Economic Flux, London.

Slezkine Y.

2017 The House of Government: A Saga of the Russian Revolution, Princeton.

Szmyt Z.

2017 Urban Shamanism in Siberia: The Dialectic of Placemaking and Fieldwork, "Historia@Teoria”, vol. 5,pp. 128-131.

Therborn G.

2017 Cities of Power: The Urban, The National, The Popular, The Global, New York. Yan A.

2012 Monument to Lenin was Dismantled and Put Up for Sale in Ulan Bator, "Inform Polis", vol. 11, p. 6.

Zhimbiev B.

2000 History of the Urbanization of a Siberian City, London. 